standing needs was some organization which would permit the free expression of scientific opinion.

That suggestion calls for some examination, for although scientists might well do more to assist the formation of informed opinion it is open for discussion how far 'scientific opinion' can exist except in the sense of considered opinion on specific scientific or professional opinion on specific issues. Such opinion could largely be formulated by existing professional institutions if they recognized their responsibility and. used their opportunities, particularly in association with, for example, the Parliamentary and Scientific Committee. Meanwhile, Mr. Brookes, in any event, has indicated some opportunities for constructive work by the professional institutions, and the British Association could well make sure that this general problem of communication is adequately discussed at future meetings as well as kept under continuous review as an aspect of the Association's function in serving the community.

\section{HUMAN ENDOCRINOLOGY}

Hormones in Human Plasma

Nature and Transport. Edited by Dr. Harry N. Antoniades. Pp. xvii + 667. (Boston, Mass.: Little, Brown and Company, Inc.; London: J. and A. Churchill, Ltd., 1960.) 25 dollars; $180 \mathrm{~s}$.

$\mathrm{T}$ HIS is a most useful book. There has long been emphasis on hormonal excretion products, too long in the view of many, simply because they are more accessible. It is good to see the increasing importance attached in the past few years to hormones in the circulating blood. Previously there had been available the book of the Ciba Foundation Symposium on Hormones in Blood, but this dealt in a less-comprehensive way with mammals generally. In the book edited by Dr. Antoniades, we have a good account by thirty-three authors of the whole subject of hormones in human plasma. This book is fully comprehensive in its treatment of hormones and the history of their discovery, and even the zoological limitation to man is only nominal. It is the first of its kind, and as Dr. Thorn says in his preface, it may well be the last, because the growth of information in this field will make it impracticable in future to compress the subject in full detail into a single volume.

The book is divided into five parts: methods of blood collection and plasma fractionation; hormones of pancreatic origin; hormones of pituitary origin; steroid hormones; and hormones produced by thyroid gland, the adrenal medulla and the placenta. This subdivision is not quite logical in that there is a potential overlap between steroid and placental hormones; discussion under the latter heading, however, is restricted to gonadotrophins. An attractive feature of the book is the integration of new knowledge with the pioneer observations. In particular, it is pleasant to see recognition given to the work of R. T. Frank, who as early as the 1930's recognized that the place to look for functionally effective œstrogens was in the circulating blood, not in the urine, but whose work, owing to technical imperfection, was largely ignored at the time. Many books published at the present time seek only to scoop off a thin layer of the cream of current knowledge without acknowledgment that it has evolved from the work of many years. The book edited by Dr. Antoniades is a welcomed exception.

In a book containing so much good material it is perhaps invidious to pick out particular parts for mention, but I myself was naturally attractod by the chapters dealing with steroid sex hormones in human plasma. That on androgens in the testis, the ovary, the adrenal cortex or as metabolic products of the corticosteroids puts the subject in proper perspective in a satisfactory way. Much the same applies to W. H. Pearlman's chapter on progesterone, which is a very complete review of the whole subject of progestagenic substances in blood and deals not only with the sources of the substances but also with their occurrence in lower mammals and even in birds, frogs and reptiles. A further chapter on steroids deals with their binding by plasma proteins. Two other chapters deal respectively with gonadotrophins. That on hypophysial gonadotrophins reflects by its brevity the relative lack of information in this field. That on extra-hypophysial substances, although it deals with pregnant mare's serum gonadotrophin, in addition to human chorionic gonadotrophin, is also somewhat sketchy. As to the rest of the book, it need scarcely be said that the chapters on insulin and related substances, on adrenocorticotrophic hormone and on thyroid hormone are very substantial. This is a reference book which should be accessible to every endocrinologist.

A. S. PARKes

\section{EVOLUTION OF MAN}

\section{Mankind Evolving}

The Evolution of the Human Species. By Prof. Theodosius Dobzhansky. Pp. xiii +381 . (New Haven, Conn. and London: Yale University Press, 1962.) 7.50 dollars; $55 s$.

T $\mathrm{O}$ branch of science is more difficult to write 1 about without bias than is the application of genetics to human history and evolution. The difficulties arise, not so much because of the possible conflict between science and theology, but because most statements about human genetics have farreaching political implications. On one hand, reformers who have wished to believe that the application of some specified social policy would cure all human ills have also found it necessary either to deny that any of the existing differences between human beings are genetic, or to assert the Lamarckian view that appropriate environmental changes will, without the need for the cruelties of natural selection, produce desirable genetic changes. On the other hand, those, from Plato onwards, who have felt that the Golden Age is in the past, and that the preservation of the status quo is the best that can be hoped for, have usually found it necessary to justify the existing differences between the 'haves' and the 'have-nots'-whether they be individuals, classes or races-by arguing that all important differences between human beings are hereditary.

Faced with these twin dangers, a few geneticists have incautiously attempted to explain the whole of human history, politics and sociology in genetic terms. A commoner, if more cowardly, attitude has been to admit the relevance of genetics in such 